\title{
Effective social planning for mine closure
}

\author{
K. Lamb Coakes Consulting, Australia \\ S. Coakes Coakes Consulting, Australia
}

\begin{abstract}
Most Australian resource companies recognise that effective community engagement enhances their corporate reputation and underpins their social licence to operate. Industry-leading companies also understand that the socio-economic impacts of their operations need to be assessed and managed with the same rigour as environmental, health and safety impacts. Some companies, however, fail to see the value of robust community engagement or socio-economic impact assessment during mine closure planning.

A robust approach to mine closure planning considers community impacts and relevant mitigation strategies in both the lead-up to mine closure and during mine closure - in fact, some would advocate that consideration of the social aspects of closure should be undertaken from the inception of a project or operation.

This paper will demonstrate a best-practice approach to assessing the socio-economic impacts of mine closure, and will outline how to engage with communities during this time of uncertainty. Through discussion of a range of practical case studies, a suite of tools will be highlighted that can be used at an operational level to assess the status of key community assets and capitals and in determining a community's sustainability when facing closure of a nearby mine. Such tools include: Community Sensitivity Analysis (Coakes and Sadler, 2011), Town Resource Cluster Analysis (Fenton et al., 2003) Stakeholder Mapping and Community Needs Assessment. In addition, effective management strategies to prepare communities for mine closure will be explored and recommended approaches to community engagement during each phase of mine closure discussed.
\end{abstract}

Mine closures can afford genuine opportunities for communities when companies are proactive, diligent, and comprehensive in their planning approach. This paper will demonstrate how companies can work with communities to leave a positive legacy and genuinely support a community's sustainability long after a mining operation is gone.

\section{Introduction}

Mining projects have the potential to create social impacts across all project phases, from exploration and planning through to final decommissioning, with the impacts experienced typically the greatest in the initial project development and closure phases as communities adapt to change. This is the case whether the project is a greenfields development or simply an extension to existing mining operations.

As 'good neighbours', companies have a responsibility to exit communities in a manner that leaves a sustainable legacy which has the opportunity to benefit future generations. However, despite the importance of the closure process, in practice it is not unusual to see planning for mine closure left to the eleventh hour, commencing only immediately prior to an operation's decommissioning phase.

This paper discusses the relevance of social impact assessment (SIA) as a framework for mine closure planning. It describes some SIA tools that can be applied in order to accurately assess and predict the likely impacts of closure and provides examples of the application of these tools in successful closure planning programs. 


\section{When to plan for closure}

Mine closure planning involves all aspects of the planning required to transition a mine to its completion state so that ownership can be transferred to another land user (DITR, 2006). Conceptual closure planning should begin at the start of a mine's development process at the conceptual or pre-feasibility phases. This is because the project team should be considering potential final land use scenarios during the design phase as small changes in the design phase can have a major implication for closure options (ICMM, 2008). The closure planning process should consider a range of potential final land uses and alternatives, and therefore should be as consultative a process as practicable with the involvement of future landowners and affected/impacted communities (Figure 1).

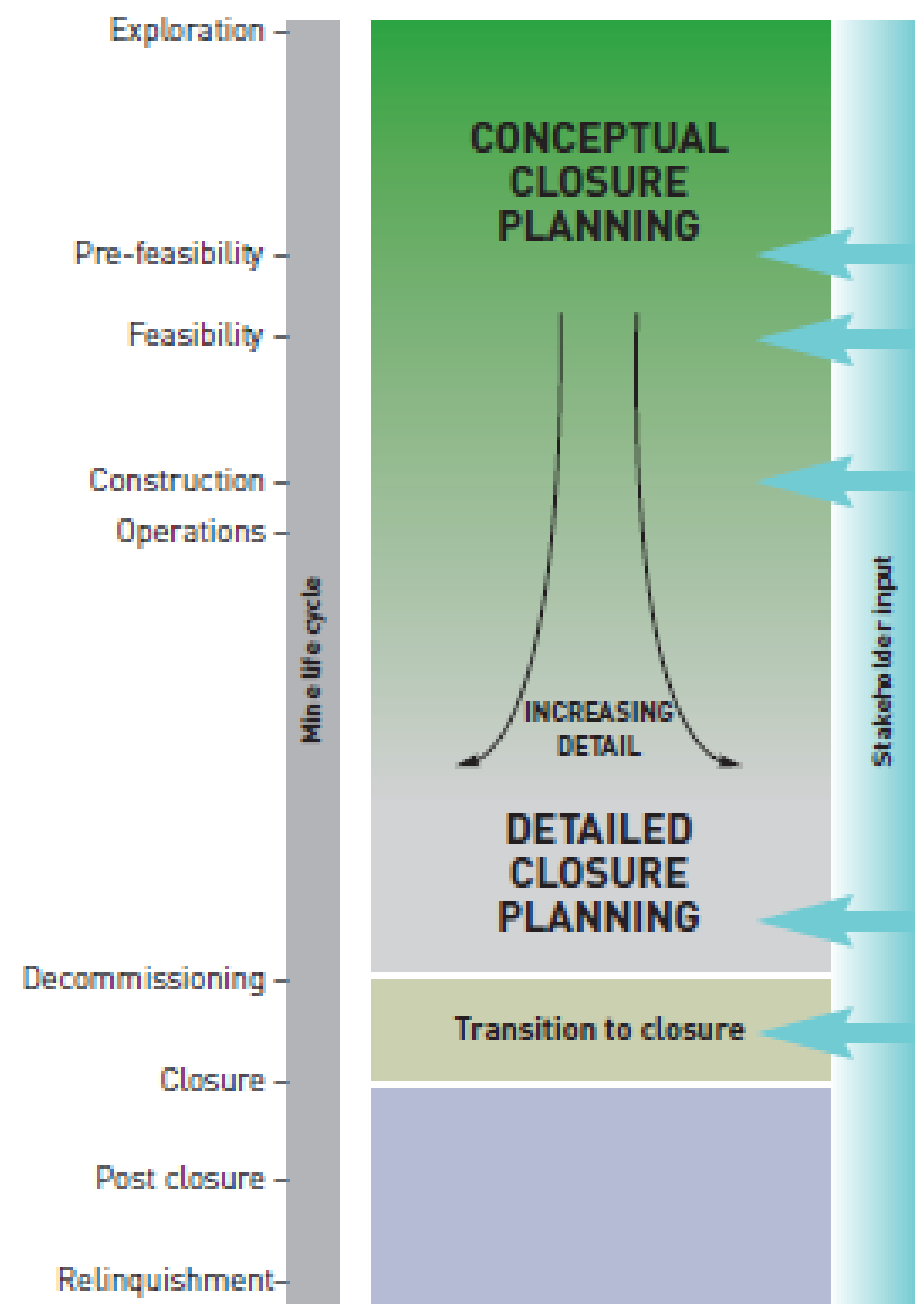

Figure 1 Closure planning in the project operational cycle (Source: ICMM, 2008)

The need for early consideration of mine closure is increasingly reflected in industry guidance notes and internal company policies and guidelines. Some examples are provided in Table 1.

However, in the authors' experience, planning for closure, from a social perspective, appears to be one of the last considerations in the project cycle; with many companies afraid that engagement in relation to closure planning will raise stakeholder expectations about final land use options that may not be feasible. Consequently, when closure planning does occur there is often limited time available to assess various options that may be more in line with community needs and aspirations. The limited assessment time also means companies are often unable to demonstrate and predict the range of social and economic impacts (across various stakeholders) associated with the closure of their operation, and hence are less able to work effectively with communities to mitigate the higher risk impacts. 


\section{Table 1 References to mine closure in existing guidance documents and industry} guidelines

\begin{tabular}{|c|c|}
\hline Guideline/Standard & Reference/Requirement \\
\hline \multirow[t]{2}{*}{$\begin{array}{l}\text { Leading Practice Sustainable } \\
\text { Development Program for the } \\
\text { Mining Industry (Principle 4) } \\
\text { (DITR, 2006) }\end{array}$} & $\begin{array}{l}\text { Consult with interested and affected parties in the identification, } \\
\text { assessment and management of all significant social, health, safety, } \\
\text { environmental and economic impacts associated with mining } \\
\text { activities (Element 4.1). }\end{array}$ \\
\hline & $\begin{array}{l}\text { Inform potentially affected parties of significant risks from mining, } \\
\text { minerals and metals operations and of the measures that will be } \\
\text { taken to manage the potential risks effectively (Element 4.3). }\end{array}$ \\
\hline $\begin{array}{l}\text { Minerals Council of Australia's } \\
\text { (MCA) Enduring Value framework } \\
\text { (MCA, 2004) }\end{array}$ & $\begin{array}{l}\text { Contribute to community development from project design } \\
\text { through closure in collaboration with host communities and their } \\
\text { representatives. }\end{array}$ \\
\hline $\begin{array}{l}\text { International Finance Corporation } \\
\text { (IFC)/World Bank Group's } \\
\text { Environmental, Health and Safety } \\
\text { Guidelines for Mining }\end{array}$ & $\begin{array}{l}\text { Closure and post-closure activities should be considered as early in } \\
\text { the planning and design stages as possible with allocated and } \\
\text { sustainable funding sources identified for the implementation of } \\
\text { the plan. The mine closure plan ensuring future public health and } \\
\text { safety are not compromised; the after-use of the site is beneficial } \\
\text { and sustainable to the affected communities in the long term; and } \\
\text { adverse socio-economic impacts are minimised and socio-economic } \\
\text { benefits are maximised. }\end{array}$ \\
\hline $\begin{array}{l}\text { International Council on Mining } \\
\text { and Metals, Planning for } \\
\text { Integrated Mine Closure Toolkit }\end{array}$ & $\begin{array}{l}\text { Closure should begin at the earliest opportunity. The earlier that } \\
\text { risks and unknowns associated with closure are identified, the } \\
\text { greater the potential for meeting specific closure objectives. } \\
\text { Closure plans should evolve over time as more information } \\
\text { becomes available. }\end{array}$ \\
\hline
\end{tabular}

\section{Applying the SIA framework to mine closure planning}

As is the case with environmental impact assessment, a process with which most mining companies are fully familiar, the SIA framework has a number of key phases. The consultant applies a six phase approach to SIA that is in line with the International Principles for Social Impact Assessment (Vanclay, 2003), AA1000 Stakeholder Engagement Standard (AccountAbility, 2011), and ISO 2006 Social Guidance Statement (International Organization for Standardization, 2011) (Figure 2).

These phases are relevant to all stages of a project's development and operation and are particularly relevant when planning for closure. The following sections of this paper discuss the SIA program phases and the application of this framework to mine closure planning.

\subsection{Profiling - understanding the closure context}

An understanding of the baseline social and economic context in which a project will operate is central to the development of a robust SIA. There is also increasing recognition of the relationship between the socioeconomic and environmental context of a project area with the IFC's recent inclusion of the theme of 'ecosystem services' in revisions to its performance standards. This theme identifies the benefits that people obtain specifically from ecosystems, for example, food, timber and protection from natural hazards.

A social profile is a comprehensive summary of the key characteristics of the people who live in or near the project area, and ultimately assists in orienting companies to the social aspects that may be relevant to project development, operation and closure. 


\section{SIA TRAINING COURSE - PROPOSED CONTENT AREAS}

\begin{tabular}{|c|c|c|c|c|c|}
\hline $\begin{array}{l}\text { PHASE I: } \\
\text { Profiling }\end{array}$ & $\begin{array}{l}\text { PHASE 2: } \\
\text { Scoping }\end{array}$ & $\begin{array}{l}\text { PHASE 3: } \\
\text { Assessment of } \\
\text { Impacts }\end{array}$ & $\begin{array}{l}\text { PHASE 4: } \\
\text { Mitigation and } \\
\text { Enhancement }\end{array}$ & $\begin{array}{l}\text { PHASE 5: } \\
\text { Reporting }\end{array}$ & $\begin{array}{l}\text { PHASE 6: } \\
\text { Monitoring. } \\
\text { Evaluation and } \\
\text { Management }\end{array}$ \\
\hline $\begin{array}{l}\text { Define project } \\
\text { parameters, actions and } \\
\text { alternatives }\end{array}$ & $\begin{array}{l}\text { Identify likely areas of } \\
\text { impacts and assessment } \\
\text { boundaries }\end{array}$ & $\begin{array}{l}\text { Collect detailed data for } \\
\text { each social impact } \\
\text { assessment variable } \\
\text { identified in phases } 1 \& 2\end{array}$ & $\begin{array}{l}\text { Propose recommenda- } \\
\text { tions on alternatives or } \\
\text { modifications to project } \\
\text { design. }\end{array}$ & Preparation of SIA report & $\begin{array}{l}\text { Identify relevant } \\
\text { monitoring and } \\
\text { evaluation variables }\end{array}$ \\
\hline $\begin{array}{l}\text { Undertake PISA and } \\
\text { social profiling to } \\
\text { define the social context } \\
\text { and to identify key } \\
\text { stakeholders }\end{array}$ & $\begin{array}{l}\text { Identify full range of } \\
\text { impacts and issues }\end{array}$ & $\begin{array}{l}\text { Determine impact } \\
\text { significance and } \\
\text { undertake a detailed } \\
\text { examination of these } \\
\text { impacts }\end{array}$ & $\begin{array}{l}\text { Explore strategies to } \\
\text { mitigate or ameliorate } \\
\text { negative impacts and to } \\
\text { enhance positive impacts, } \\
\text { including consideration } \\
\text { of community } \\
\text { partnerships and } \\
\text { investment programs }\end{array}$ & $\begin{array}{l}\text { Integration of SIA } \\
\text { outcomes into broader } \\
\text { EIA/EA reporting }\end{array}$ & $\begin{array}{l}\text { Establish evaluation } \\
\text { and monitoring } \\
\text { tools/instruments }\end{array}$ \\
\hline $\begin{array}{l}\text { Describe proposed action } \\
\text { in context of current } \\
\text { social context and } \\
\text { historical trends }\end{array}$ & $\begin{array}{l}\text { Identify variables to be } \\
\text { further assessed/ } \\
\text { measured and likely } \\
\text { links between social } \\
\text { and bio-physical } \\
\text { variables/impacts }\end{array}$ & $\begin{array}{l}\text { Project and estimate } \\
\text { impacts and likely } \\
\text { responses }\end{array}$ & $\begin{array}{l}\text { Strategies developed } \\
\text { to manage impacts } \\
\text { associated with the } \\
\text { proposed change }\end{array}$ & $\begin{array}{l}\text { Seek feedback on } \\
\text { SIA report }\end{array}$ & $\begin{array}{l}\text { Develop monitoring and } \\
\text { evaluation program }\end{array}$ \\
\hline $\begin{array}{l}\text { Develop a public } \\
\text { participation program } \\
\text { or stakeholder } \\
\text { engagement plan }\end{array}$ & $\begin{array}{l}\text { Seek feedback on } \\
\text { identified issues and } \\
\text { impacts }\end{array}$ & $\begin{array}{l}\text { Seek feedback on } \\
\text { projection and } \\
\text { estimation of impacts } \\
\text { and responses }\end{array}$ & $\begin{array}{l}\text { Seek feedback on } \\
\text { proposed strategies }\end{array}$ & $\begin{array}{l}\text { Public exhibition of } \\
\text { assessment outcomes }\end{array}$ & $\begin{array}{l}\text { Recommendations of } \\
\text { SIA to be incorporated } \\
\text { into PPPP }\end{array}$ \\
\hline
\end{tabular}

\section{Figure 2 Social impact assessment framework}

The profiling phase is used to consider the changes that have occurred in the community over time and to set a baseline from which impacts may be predicted. In the context of closure planning, the development of a socio-economic profile at the beginning of a project allows the project proponent to develop a sound understanding of the nature of the community in which it will operate. During operations, an updated profile helps a company to better understand how its presence has influenced the local and regional social and economic environment, through its linkages and associations. The collation and analysis of such information at the start of a project and then on occasions during operations (for example, after a new census is released) is essential in defining the extent of impact that may be associated with the eventual closure of a mining operation. Prior to closure, an updated profile assists with impact prediction and mitigation planning.

A profile is developed through a review and analysis of information sources including:

- Social indicator data, including Australian Bureau of Statistics (ABS) census information.

- Reports and studies relevant to the assessment area, e.g. local government land use and strategic plans.

- Local media to identify salient stakeholder/community issues, challenges, needs and priorities.

In order to comprehensively assess a community's capacity (or resilience) to adapt to changes brought about by a project/operation and its eventual closure, Coakes Consulting has developed a composite index 
that assesses the vulnerability or sensitivity of a community's key assets - natural, economic, physical, human and social assets.

\subsubsection{Case study 1: community sensitivity analysis}

As outlined in Coakes and Sadler (2011) considerable research has been undertaken to consider what makes a community strong and resilient to change. The potential of a system to adjust to and manage change effectively is usually referred to as its resilience and/or adaptive capacity; a higher resilience results in a lower risk of a community not coping with change.

In many areas where mining takes place, the mining industry is a key source of economic support for surrounding communities and contributes significantly to regional economic development (DITR, 2006). The socio-economic changes that occur when a mine closes, therefore, can be significant for local populations based on the associations and partnerships the operation has built up over time, such as local employment, social investment, etc.

A social profile developed for a closure planning process should identify key community assets which are imperative to ensuring community resilience over time, and should also address how community capacity can be enhanced to further develop capital assets to facilitate more effective management of threat or risk. According to a number of sustainable society theorists (e.g. Beckley et al., 2002; DFID, 1999; Ellis, 2000; Hart, 1999) there are five key capital areas that should be assessed to define levels of community resilience. These include human, social, economic, built/physical and natural capitals, as illustrated in Figure 3.

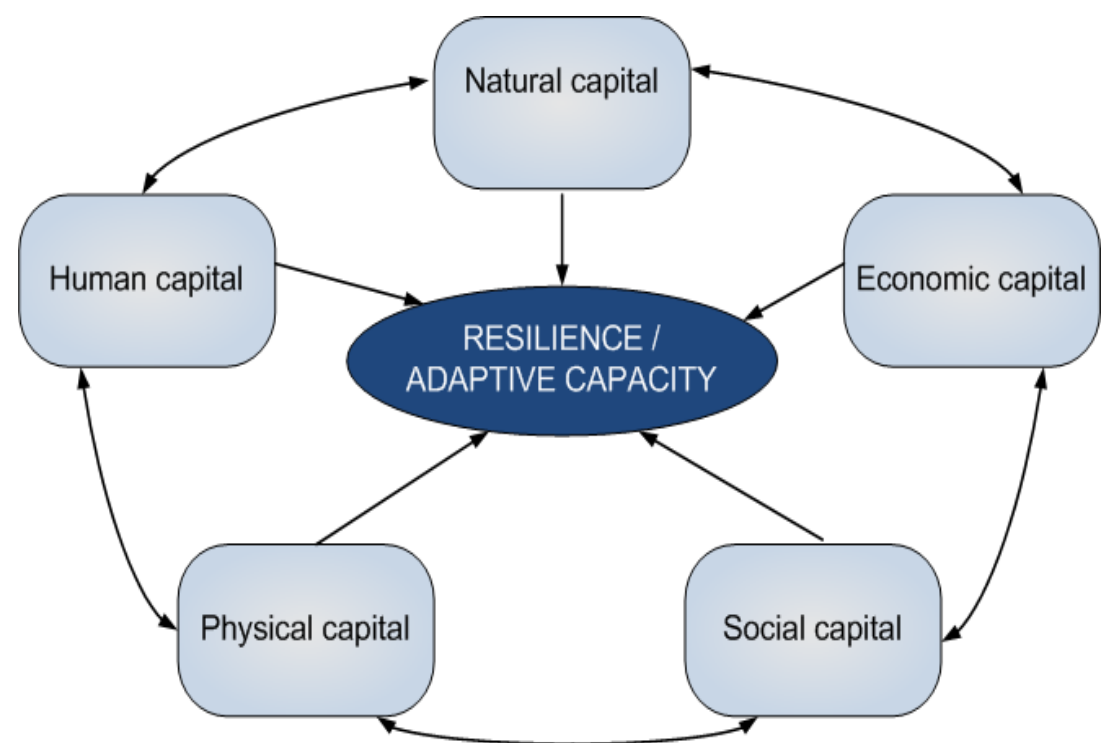

Figure 3 Community capitals framework@ (Source: Coakes and Sadler, 2011)

Note: In the context of SIA practice, the Community Capitals framework has been developed to assess community sensitivity/vulnerability to change.

Some examples of aspects that may comprise these capitals are also summarised in Figure 4.

Identification of indicators that relate to each of these capital areas, at the profiling stage of closure planning, will help to assess community dependency on the operation, as well as provide a reading of the overall wellbeing and socio-economic status of the locality. An operation may then choose to focus its social investment strategy on building capacity in more vulnerable capital areas to assist communities to prepare for changes associated with closure. 


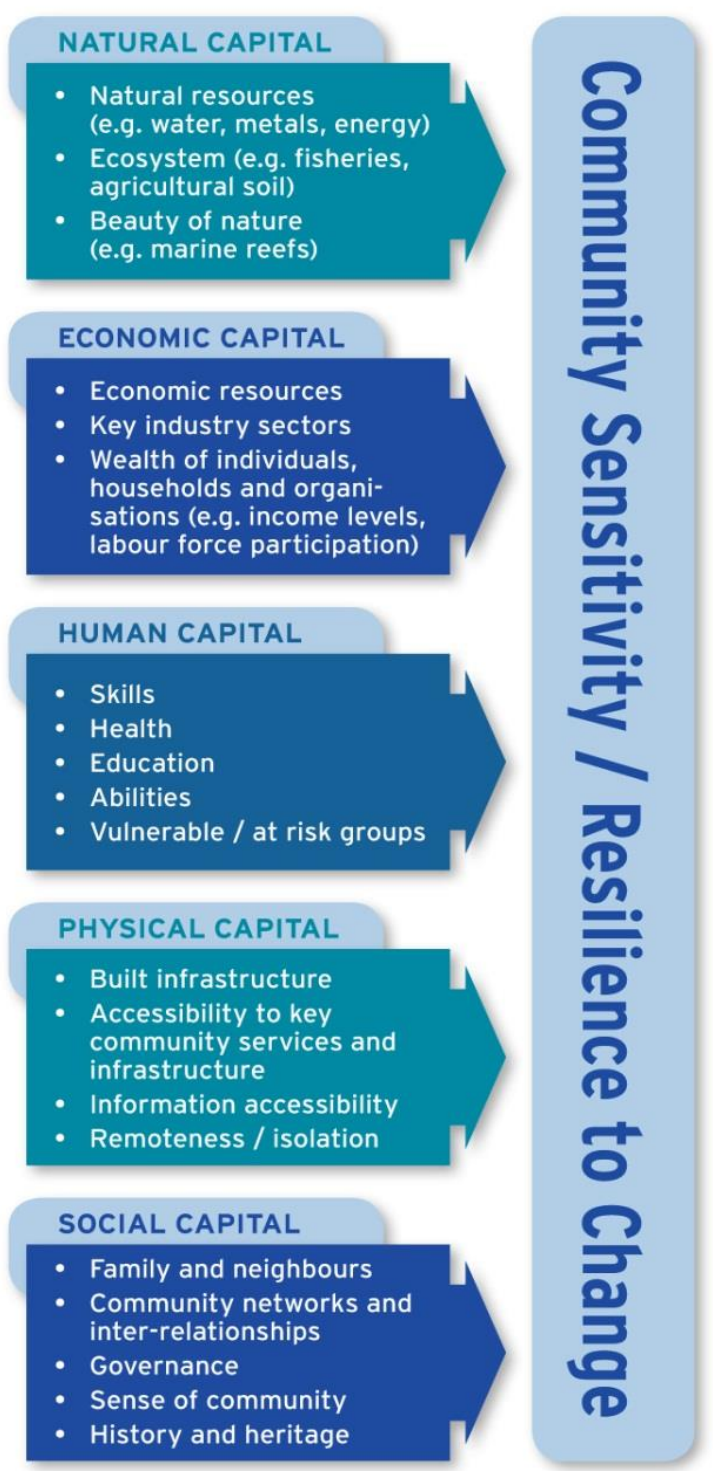

Figure 4 Elements of the five capital areas (Source: Coakes and Sadler, 2011)

\subsection{Scoping the issues associated with closure}

The scoping phase of a SIA provides the opportunity to gauge stakeholder issues and concerns in relation to proposed closure of an operation by identifying:

- Stakeholder issues in relation to closure.

- Possible strategies and solutions for addressing the issues raised that take into account community needs and aspirations.

- Potential post-closure land use options for further assessment and consideration.

Consultation mechanisms that can be employed during this scoping phase might include standard tools such as semi-structured interviews; stakeholder briefings and presentations; community and service provider surveys; and workshops and information sessions. In designing an appropriate consultation process for closure, it is important to recognise that creative solutions come from creative process. Examples of some more creative mechanisms to involve the community in closure planning may include:

- Design games and charrettes: a highly visual way of allowing people to explore physical design and post closure land use options. 
- Community visioning and dialogues: to formulate a collective vision for the community - a roadmap for future community development.

- Community planning forums: forums to afford community members to generate ideas through interactive displays, group debate and smaller workshop groups.

It is important that traditionally hard to reach groups such as disadvantaged or marginalised minority groups are also not excluded from the closure planning consultation process. Engagement techniques need to be matched to the particular groups being consulted and may be more formal or informal, structured and unstructured in nature, depending upon the individuals and groups to be consulted. SIA has always considered the impacts of change on 'at-risk' groups and consequently, such groups would be sought out as part of appropriate planning for a closure engagement program. Stakeholders who are typically involved in this scoping phase will be drawn from the groups outlined in Figure 5. It should be noted that closure, like project development, will bring positive impacts for some stakeholders and more negative impacts for others. Should negative impacts be predicted, it is the role of the SIA to identify how such impacts should be effectively managed.

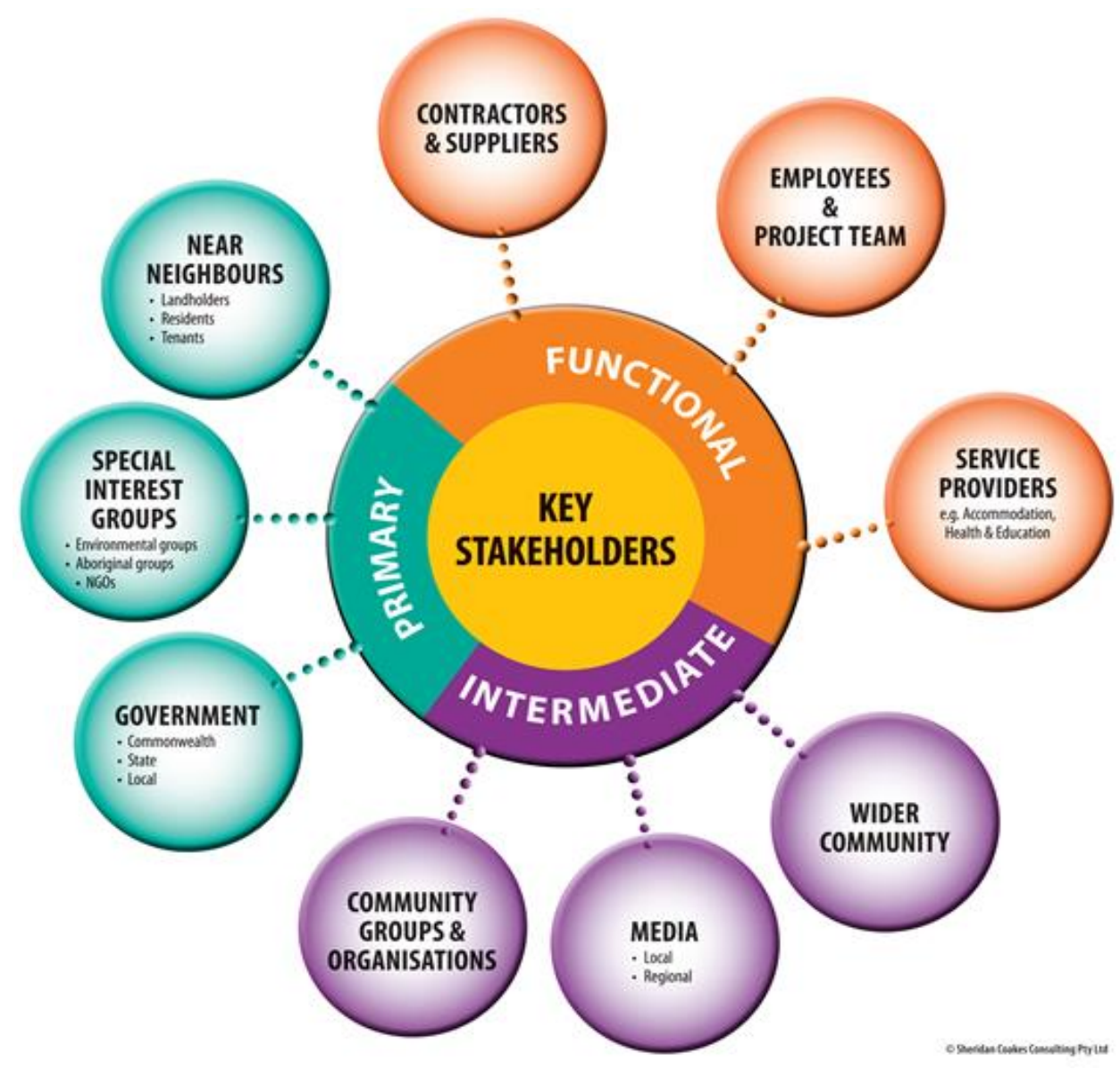

Figure 5 Mapping key stakeholders () (Source: Coakes Consulting, 2011)

\subsubsection{Case study 2: Photovoice}

Photovoice is an innovative method of needs/values assessment and community visioning that has been used in a range of settings to provide community members/key stakeholders with an opportunity to 'paint a picture' of community life in their own terms (Refer to example presented in Figure 6). Using the medium of photography, Photovoice allows community members to document their lived reality, concerns, hopes, and aspirations for the future. The photographs generated in the process present an opportunity to record a baseline of community perception, experience, and function and examine changes in community attitudes over time. 
The technique is particularly effective when applied with certain groups such as children, youth, Aboriginal communities, and migrants, may result in a range of 'centrepiece' community outcomes such as a photographic display, a school book or calendar, school sculpture, mosaic, art piece et cetera. Questions to be used for a Photovoice project for mine closure should be framed to capture the values and aspirations of community members in the present as well as into the future (post-closure).

Mine developers can then use this information to assist in deciding what future investments would be of most benefit to community members and therefore potential final land use options to be considered.

Figure 6 captures some examples of Photovoice outcomes that highlight local community values.

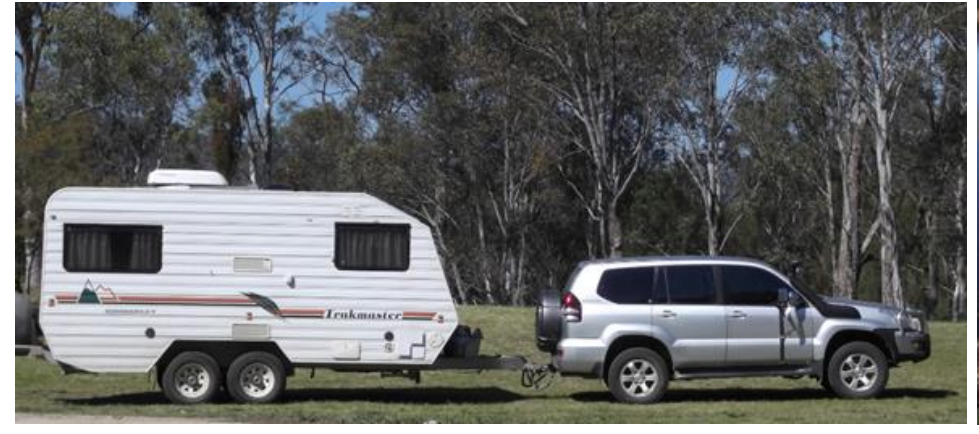

"This picture is important because there are more tourists to come here and look around. It makes me feel like people want to come here. I like it."

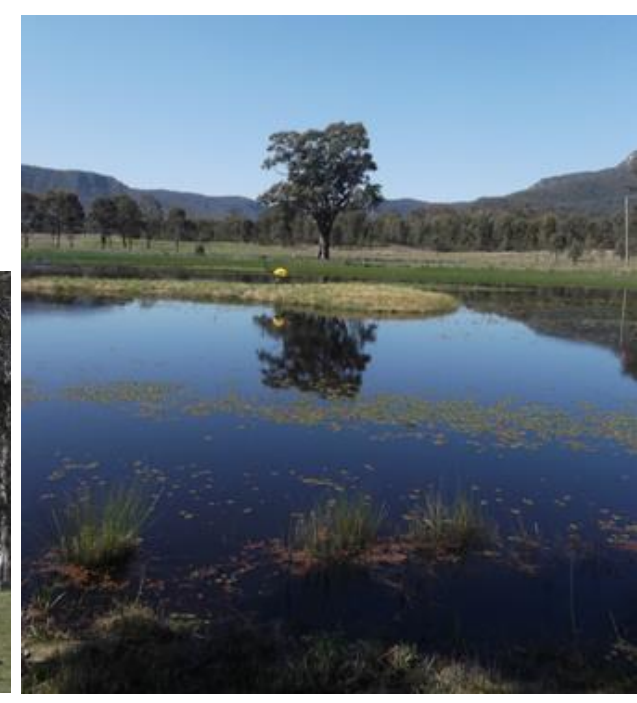

"I took this picture because it shows the beautiful nature of our town and everything in it. It makes my heart race. The nature of the native animals and where they live."

\section{Figure 6 Photovoice examples: community values}

\subsubsection{Case study 3: CNA for a mine closure}

Community Needs Assessment (CNA) is a way of gathering information about a community's assets, requirements, challenges, and desires. The process aims to determine the 'gaps' between the existing and desired conditions, and then use this information to guide investments to improve the socio-economic environment. The information used for a CNA is typically gathered through stakeholder consultation and review of appropriate data sources, such as population statistics and infrastructure audits. It uses the data to evaluate expressed, felt and normative needs.

A CNA has recently been completed by the consultant to support the planned closure of diamond mine in northern Western Australia. The CNA was used to identify the social needs of the local communities in terms of infrastructure, services, and conditions, and to identify stakeholder perceptions of the social impacts and opportunities of closure and how such impacts could be best managed/mitigated. The assessment employed a range of data collection techniques, such as profiling the existing social environment, stakeholder interviews, and community workshops to understand community needs and aspirations. The CNA report then recommended a range of corporate social investment opportunities to assist in addressing community needs and facilitating change associated with closure from a community perspective. 


\subsection{Assessing the impacts}

The assessment phase assesses both positive and negative of different closure options, and integrates social aspects of mine closure with other assessment inputs, such as environmental, economic, etc.

Questions addressed during this phase include:

- Are the potential impacts factual, that is are they likely to occur?

- Are the project impacts likely to be experienced by all persons or will the impacts be specific to certain individuals, stakeholders or special interest groups?

- What importance or weight is to be attached to the impact(s)?

- Which issues/impacts can be addressed in the closure planning design?

Within a mine closure context, such an assessment may also include consideration of the following aspects:

- The potential effect of closure on communities of interest and relevant stakeholders.

- The likely interaction between stakeholders and potential final landform options.

- Existing interaction between the mine and the local community, including employee.

- Identification of the potential primary socio-economic costs and benefits of mine closure.

When assessing potential impacts of mine closure, local residents will often express concern regarding changing demographics and loss of community participation and membership. Consequently, early involvement of stakeholders and assessment of potential land use options post closure could provide greater certainty to community members that when the mine ceases to exist, 'all will not be lost'.

\subsubsection{Case study 4: town resource cluster analysis}

In order to comprehensively identify the potential socio-economic impacts of a client's proposed closure of a colliery, the consultant undertook a confidential survey of all employees and contractors employed at the colliery that was structured to collect information including education and employment history; residential patterns and household structure; expenditure patterns; use of local services and contributions to the local community; intentions post-closure with respect to location of residence; preferences for employment assistance and support services; views on future site uses post closure; and perceived impacts on the community resulting from closure of the colliery.

The completion of this survey achieved a number of objectives:

1. Development of a comprehensive profile of the existing operation and employees in the region (Phase 1).

2. Identification of stakeholder issues, including those of employees (Phase 2).

3. Generation of creative ideas about final land use.

4. A socio-economic assessment of residential and expenditure patterns.

The consultant then applied Town Resource Cluster (TRC) analysis to establish a relationship between the mining project and specific communities (TRCs). TRC Analysis is a technique (Fenton et al., 2003) used to identify the direct and indirect associations and linkages between the use of a resource and people that may be impacted by change associated with that resource. Initially applied within a forest planning context, the methodology has been further implemented in other resource sectors where management of change has been a concern, e.g. mine development and closure, fisheries management. The primary objective of TRC analysis in the current context was to identify towns with a direct or indirect dependency on the mine and then allow for further spatial analysis to focus on the specific communities that were likely be affected by its closure rather than those simply in proximity to the mine. Such a relationship allows for an 
understanding of the potential socio-economic impacts likely to be experienced by communities and townships as a result of changes in a mining operation's lifecycle.

The TRC analysis focused on social and economic contributions made by mine employees, contractors and suppliers, based on surveys of these particular stakeholder groups. The results of the survey enabled a better understanding of social impacts such as: the common characteristics of employees, contractors and suppliers; the locations of residence of employees and contractors; participation in community groups; and utilisation of health and education services. Economic contributions were also examined and focussed on supplier expenditure and employee household expenditure. By combining these extrapolated contributions, an understanding can be reached of the social and economic contributions the operation makes to the surrounding communities and the likely impacts of closure (refer to the example presented in Figure 7) (Coakes, 2009a, 2009b).

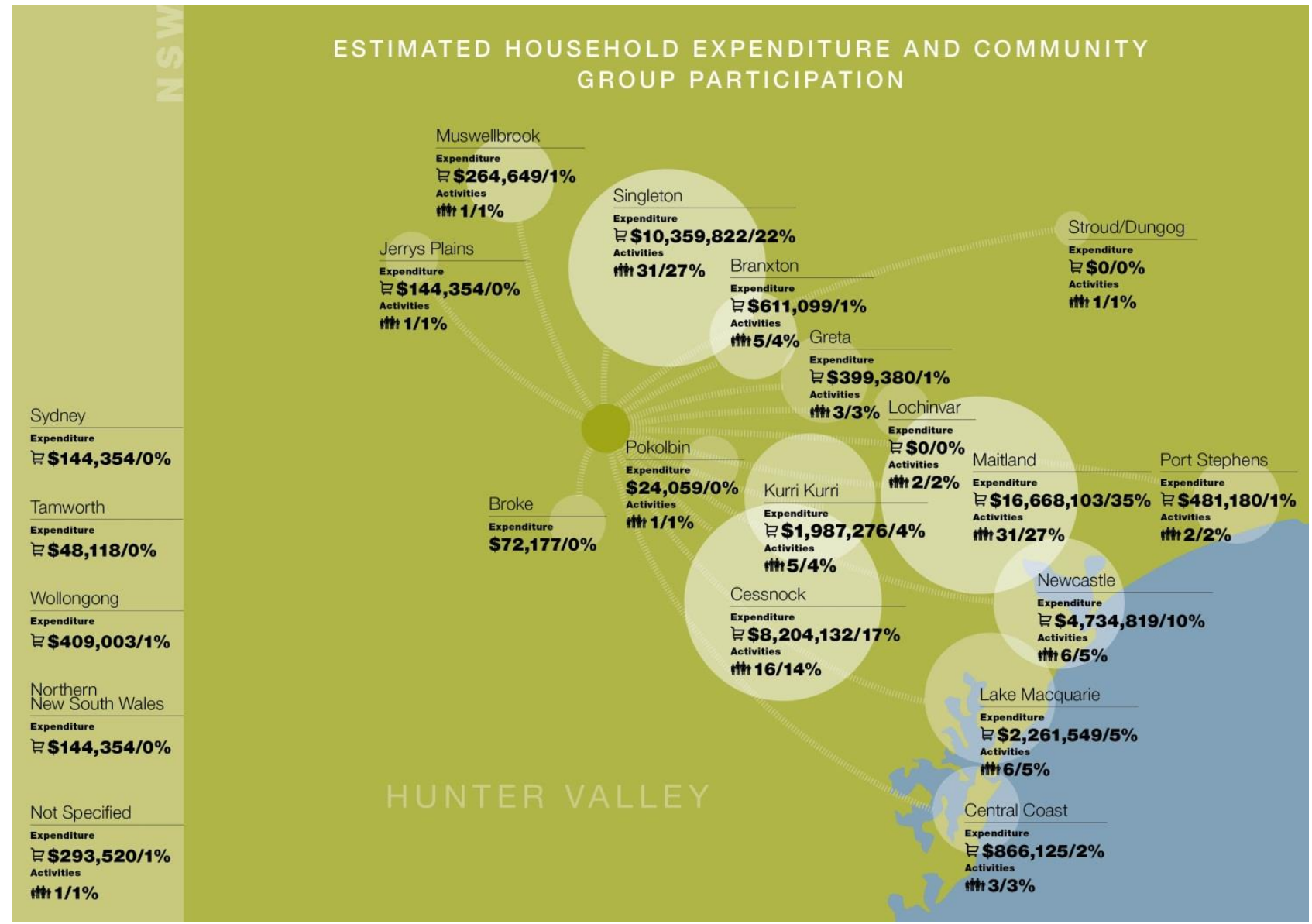

\section{Figure 7 Example of TRC analysis output: employee household expenditure and involvement in community activities}

\subsubsection{Case study 5: mapping community values}

Values mapping is an example of another tool used by the consultant as part of the SIA process that assists companies to in obtaining a better understanding of associations, dependencies and uses of an area/locality from differing stakeholder perspectives. In the context of mine closure planning, an improved understanding of what is important to a community is useful in identifying community needs and aspirations with respect to post closure land uses; and ensuring social and economic sustainability post the exit/closure of particular industry activities. An example of a thematic values map for a Port Infrastructure Project in NSW is provided in Figure 8. Areas of darker colour indicate those areas most valued by community stakeholders for commercial, recreational, educational, environmental and social reasons. 


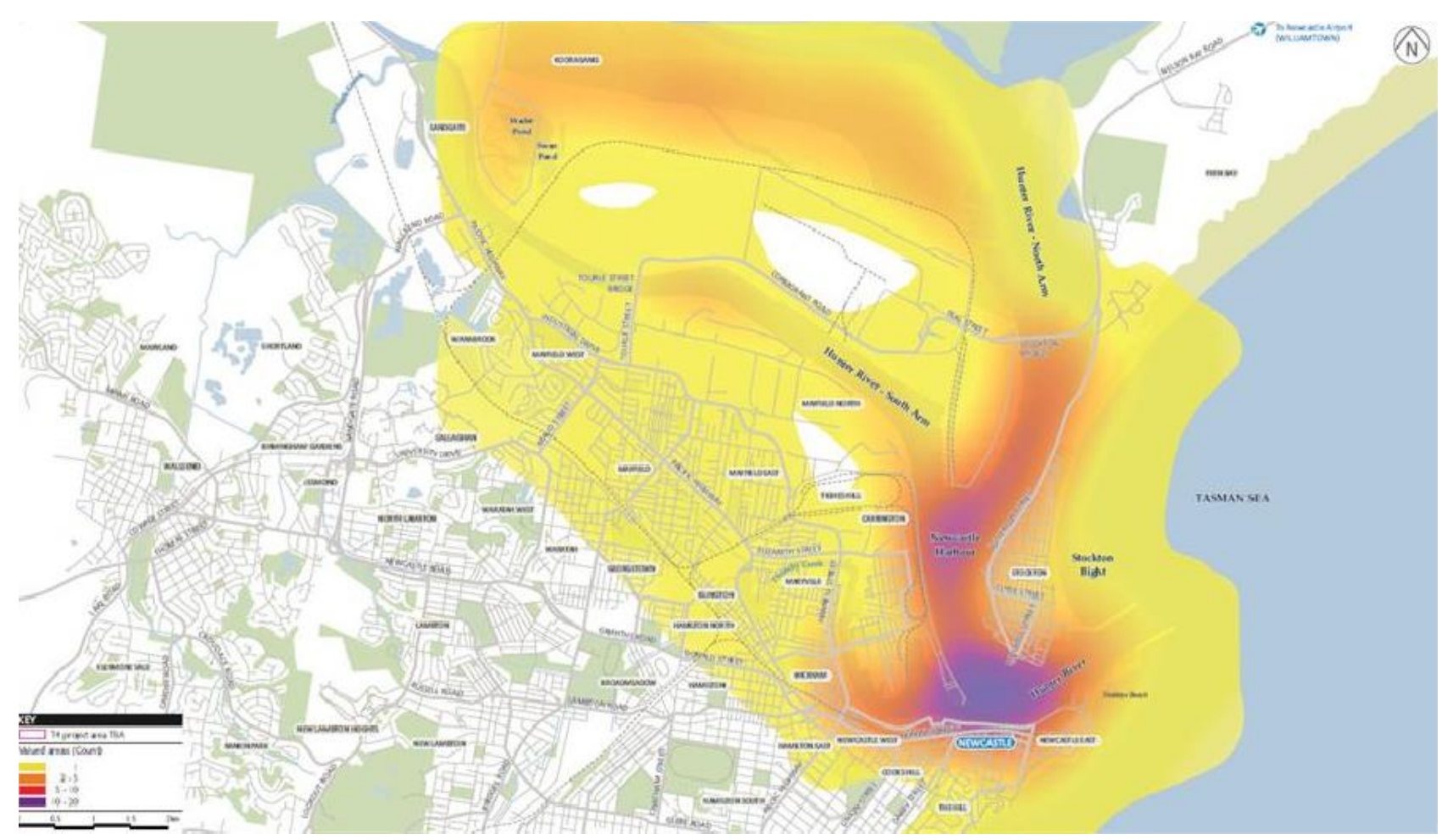

Figure 8 Example of thematic map of valued areas

\subsubsection{Case study 6: participatory multi-criteria analysis}

The use of tools such as multi-criteria analysis can assist in decision making and selection of potential closure options that may be more acceptable for consideration in closure planning.

This tool can be used to enable the interactive and consultative assessment of potential closure options. The technique can enable a comparison of closure options across a range of identified criteria (social, economic and environmental) with a workshop process providing an opportunity to assess each option according to the criteria developed; and to weight each option according to different stakeholder preferences. The tool provides the flexibility to adjust weightings and test trade-off scenarios in an interactive forum, and therefore can be used with different stakeholder groups to rank closure options. The outcome is a priority ranking of closure options for further company consideration.

\subsection{Managing predicted impacts}

All projects in Australia are required to implement strategies to mitigate negative impacts and enhance the positive benefits associated with a project's development, operation and eventual closure. In the context of mine closure, the strategy development process can greatly assist in developing alternate futures for a locality or area post-mining, particularly through strategic social investment that facilitates the preferred end land-use option. It can also provide an opportunity for stakeholders to become involved in developing solutions for closure issues, and participate in the management of the change process as different stages of closure occur.

Examples of strategies that can be used to mitigate potential impacts associated with project closure and their correlation to standard management measures during a project's operation are illustrated in Table 2 .

\subsubsection{Case study 7: development of a community development fund}

The consultant has worked closely with an international mining company in the development of a Community Fund to support the company's longer term plan for community involvement and investment in the local and regional area and to contribute to the local community's sustainability post mining. Targeted consultation was undertaken to identify community needs and aspirations in the project area so that the 
Fund recognised and built on existing social structures and plans, and also focused on funding capacitybuilding projects that provided significant and ongoing benefits, beyond the life of the project.

A fund structure was developed that included two main project areas - a partnership project stream and a community donations program. A governance structure for ongoing management of the fund internally out of operating expenditure was also developed. Appropriate measures were also identified to monitor the program over time in order to evaluate the success of Fund activities at the end of the life of the project.

\section{Table 2 Examples of management measures for closure}

\begin{tabular}{|c|c|c|}
\hline Measure & Project Development and Operation & Project Closure \\
\hline Communication Plan & $\begin{array}{l}\text { Outlines key messages about the } \\
\text { project development process, } \\
\text { proposed consultation and information } \\
\text { provision activities and timing. }\end{array}$ & $\begin{array}{l}\text { Outlines key messages about the } \\
\text { project closure process, proposed } \\
\text { consultation and information } \\
\text { provision activities and timing. }\end{array}$ \\
\hline $\begin{array}{l}\text { Business Supplier } \\
\text { Workshops }\end{array}$ & $\begin{array}{l}\text { Informs business partners about the } \\
\text { Project, anticipated requirements and } \\
\text { opportunities for local businesses } \\
\text { during closure and the phasing of } \\
\text { ongoing supply requirements. }\end{array}$ & $\begin{array}{l}\text { Informs business partners about the } \\
\text { closure plan, expected requirements } \\
\text { and opportunities for local } \\
\text { businesses during closure and the } \\
\text { phasing down of ongoing supply } \\
\text { requirements. }\end{array}$ \\
\hline $\begin{array}{l}\text { Workforce } \\
\text { Management Strategy } \\
\text { (including Employment } \\
\text { Plan and Social } \\
\text { Investment Programs) }\end{array}$ & $\begin{array}{l}\text { A register of employee skills to enable } \\
\text { more effective training of potential } \\
\text { employees at project construction and } \\
\text { operation. }\end{array}$ & $\begin{array}{l}\text { A register of employee skills to } \\
\text { enable more effective placement of } \\
\text { employees post closure or to } \\
\text { facilitate the development of } \\
\text { effective retraining packages. }\end{array}$ \\
\hline $\begin{array}{l}\text { Social Investment } \\
\text { Strategy/Community } \\
\text { Development Fund }\end{array}$ & $\begin{array}{l}\text { Provides a strategic framework for the } \\
\text { establishment of community } \\
\text { development funds or for social } \\
\text { investment programs and initiatives } \\
\text { that support local community needs } \\
\text { and aspirations. }\end{array}$ & $\begin{array}{l}\text { Provides a direction for the } \\
\text { establishment of community } \\
\text { development funds or social } \\
\text { investment programs and initiatives } \\
\text { to assist local communities in the } \\
\text { transition to a post-mine scenario. } \\
\text { Requires attention to exit strategies } \\
\text { for funding. }\end{array}$ \\
\hline
\end{tabular}

\subsection{Monitoring and evaluation}

A monitoring program needs to be developed to evaluate the change process and to facilitate and inform both company and community learning for the future. This phase involves the incorporation of assessment outcomes into the mine closure plan, and development of a set of social indicators that can be used to monitor salient social impacts throughout the closure process. This phase usually also involves companies adjusting other 'social monitoring' tools they have in place, such as stakeholder perception surveys, reporting on trends in community complaints, and community consultative committees.

As with any impact monitoring program, regardless of the stage of the project, the monitoring should be sensitive to changes in:

- state, regional and local government strategies

- community demographics

- economic climate

- community needs and aspirations 
- sense of community

- interactions between the environment and local communities.

If proper SIA monitoring has been undertaken during mine operations, such aspects will naturally have been captured through this regime and will therefore continue through the closure phase. Effective social impact monitoring over the life of a mining project is an area requiring further development. The lack of specialist social science skill sets within industry is seen to harbour this development, creating a greater reliance on external consultant assistance and a lack of 'buy-in' by companies to the development of robust indicator monitoring frameworks.

\section{Conclusion}

The framework for defining effective end land uses and facilitating the development of sustainable communities' post-mine closure already exists with the SIA methodology. The framework allows for both a comprehensive social assessment and consultative approach to mine closure planning and impact management from early project development stages through to closure. However, full integration of social aspects in closure planning is still in its infancy given that such aspects are still not fully integrated in other aspects of mine lifecycle planning.

The ongoing challenge is to increase the capacity of companies to understand community values, needs and aspirations; to be more proficient in the use and analysis of 'social data'; and to integrate social assessment practice more centrally within business and operational practice.

This paper has provided a number of examples of how SIA and the social data it produces can be used at various project stages to support mine closure planning that contributes towards sustainable social development for project-affected communities.

It has demonstrated how the use of SIA practice and effective stakeholder engagement can help mining companies to leave a positive legacy after mine completion for the benefit of all parties - business and community.

\section{References}

AccountAbility (2011) AA1000 Stakeholder Engagement Standard, viewed 22 June 2012, http://www.accountability.org/aboutus/publications/aa1000-1.html.

Beckley, T., Nadeau, S., Wall, E. and Martz, D. (2002) Multiple capacities, multiple outcomes: delving deeper into the meaning of community capacity, Paper presented at the Annual Meeting of the Rural Sociological Society, August 14-17, Congress Plaza Hotel, Chicago, IL.

Coakes, S. (2009a) Victoria's forestry communities: adapting to change in the forestry industries, Report prepared for Department of Primary Industries, Melbourne, Victoria.

Coakes, S. (2009b) Pilbara Coast TRC case study, Report prepared for Department of Climate Change, Perth, Western Australia.

Coakes, S. and Sadler, A. (2011) Utilizing a sustainable livelihoods approach to inform a social impact assessment practice,

F. Vanclay and A.M. Esteves (eds), New Directions in Social Impact Assessment, Edward Elgar, UK.

DFID (1999) Department for International Development, Sustainable livelihoods guidance sheets, London.

DITR (2006) Department of Industry Tourism and Resources, Mine closure and completion: leading practice sustainable development program for the mining industry.

Ellis, F. (2000) Rural livelihoods and diversity in developing countries, Oxford University Press, England.

Fenton, M., Coakes, S. and Marshall, N. (2003) Vulnerability and capacity measurement, in The International Handbook of Social Impact Assessment, H. Becker and F. Vanclay (eds), Cheltenham, UK, Edward Elgar Publishing, pp. 211-230.

Hart, M. (1999) Guide to sustainable community indicators, Ipswich, MA, QLF/Atlantic Centre for the Environment.

ICMM (2008) International Council of Mining and Metals. Planning for integrated mine closure toolkit, London.

International Organization for Standardization (2011) ISO 26000 - Social responsibility.

MCA (2004) Minerals Council of Australia. Enduring value - the Australian miners industry framework for sustainable development, Minerals Council of Australia, Canberra.

Vanclay, F. (2003) International principles for social impact assessment, Impact Assessment and Project Appraisal, Vol. 21, pp. 5-11. 
